\title{
MODEL PEMBELAJARAN TEAM ASSISTED INDIVIDUALIZATION (TAI) DILENGKAPI DENGAN LKS BERBASIS DRILL AND PRACTICE PADA MATERI HIDROLISIS UNTUK MENINGKATKAN PRESTASI BELAJAR DAN KEMAMPUAN ANALISIS
}

\author{
Ridho Rahmadii, Mohammad Masykuri*, dan Elfi Susanti VH \\ Program Studi Pendidikan Kimia, FKIP, Universitas Sebelas Maret, Surakarta, Indonesia \\ *Keperluan korespondensi, telp: 08121500634, email: mmasykuri@yahoo.com
}

\begin{abstract}
ABSTRAK
Penelitian ini bertujuan untuk meningkatkan prestasi belajar siswa dan kemampuan analisis siswa pada materi pokok Hidrolisis menggunakan model pembelajaran Team Assisted Individualization (TAI) dilengkapi media LKS berbasis Drill and Practice. Penelitian ini merupakan Penelitian Tindakan Kelas (PTK) yang dilaksanakan dalam dua siklus, dengan tiap siklus terdiri atas perencanaan tindakan, pelaksanaan tindakan, observasi, dan refleksi. Subjek Penelitian adalah siswa kelas XI IPA 4 SMA Negeri 2 Boyolali yang berjumlah 34 siswa. Sumber data berasal dari guru dan siswa. Teknik pengumpulan data adalah dengan tes dan non tes (observasi, wawancara, kajian dokumen, dan angket). Analisis data menggunakan teknik analisis deskriptif kualitatif. Kesimpulan yang diperoleh dari penelitian ini adalah penerapan model pembelajaran Team Assisted Individualization (TAI) dilengkapi media LKS berbasis Drill and Practice dapat meningkatkan prestasi belajar siswa dan kemampuan analisis siswa pada materi hidrolisis. Ketuntasan belajar kognitif siswa pada siklus I adalah $58,82 \%$ meningkat menjadi $79,41 \%$ pada siklus II. Ketuntasan aspek afektif $94 \%$ pada siklus I meningkat menjadi $97 \%$ pada siklus II. Ketuntasan aspek psikomotor sebesar $80 \%$ pada siklus I. Sedangkan ketuntasan kemampuan analisis siswa sebesar $50 \%$ pada siklus I meningkat menjadi $70,58 \%$ pada siklus II.
\end{abstract}

Kata Kunci: Team Assisted Individualization, LKS Drill and Practice, prestasi belajar, kemampuan analisis, hidrolisis

\section{PENDAHULUAN}

Sistem pendidikan dan pengajaran di Indonesia menunjukkan perkembangan yang cukup pesat seiring dengan kemajuan zaman. Pendidikan bersifat dinamis yakni perlu selalu berkermbang secara terus menerus. Perombakan dan pembaharuan dilaksanakan dengan tujuan agar sistem yang ada dapat bermanfaat dalam pembentukan sumber daya manusia (SDM) di Indonesia. Usaha perombakan dan pembaharuan diantaranya adalah pemerintah secara terus menerus berupaya meningkatkan kualitas dan kuantitas pendidikan yang ada di Indonesia.

Upaya Peningkatan kualitas pendidikan diantaranya peningkatan sarana dan prasarana, perubahan kurikulum dan proses belajar mengajar, peningkatan kualitas guru, penyempurnaan sistem penilaian, dan usaha-usaha lain dalam komponen pendidikan. Sedangkan upaya untuk meningkatkan kuantitas pendidikan diantaranya pro- 
gram kejar paket $A$, peningkatan wajib belajar, sistem belajar jarak jauh, dan lain-lain [1]. Perombakan dan pembaharuan sistem pendidikan ini disesuaikan dengan perkembangan masyarakat serta perkembangan ilmu pengetahuan dan teknologi agar bangsa Indonesia mampu sejajar dengan bangsa-bangsa lain di dunia.

Salah satu unsur penting dalam dunia pendidikan adalah rencana kegiatan yang diatur dalam sebuah kurikulum. Dalam perkembangannya, Indonesia telah mengalami pergantian kurikulum. Pada tahun 2006, pemerintah mengeluarkan Kurikulum Tingkat Satuan Pendidikan (KTSP) sebagai pengembangan dari kurikulum 2004, untuk diterapkan pada jenjang pendidikan dasar dan menengah mulai tahun pelajaran 2006/2007.

Kurikulum KTSP berlaku untuk jenjang pendidikan SD hingga SMA. Kurikulum Tingkat Satuan Pendidikan (KTSP) yang berlaku saat ini dikembangkan berdasarkan Standar Isi (SI), Standar Kompetensi (SK), Standar Kompetensi Lulusan (SKL) dan berpedo-man pada panduan penyusunan kurikulum yang disusun oleh Badan Standar Nasional Pendidikan (BSNP) serta mempertimbangkan pertimbangan dari komite sekolah/madrasah [2]. Pada kurikulum KTSP guru tidak lagi menjadi pusat pembelajaran (Teacher Centered Learning), melainkan siswa harus aktif dalam kegiatan pembelajaran dan menjadi pusat pembelajaran (Student Centered Learning) sementara guru hanya sebagai fasilitator.

Upaya untuk mengembangkan KTSP tersebut, maka dilakukan suatu tindakan pada kegiatan belajar mengajar, khususnya di dalam kelas. Pada kurikulum ini pendekatan yang digunakan tidak lagi berpusat pada guru, melainkan siswa yang harus lebih aktif dalam kegiatan pembelajaran, maka tindakan yang perlu dilakukan adalah tindakan kelas, yang berorientasi pada kebutuhan belajar siswa, yaitu melalui sebuah penelitian tindakan kelas (PTK) atau Classroom Action Research (CAR) [3].

Salah satu mata pelajaran yang diajarkan di SMA adalah kimia. Kimia merupakan salah satu cabang sains yang berisi pengetahuan yang berdasarkan fakta, hasil pemikiran dan hasil penilitian yang dilakukan para ahli. Kimia digunakan dalam kehidupan sehari-hari, namun banyak orang menganggap bahwa ilmu kimia sebagai ilmu yang tidak menarik.

Kesulitan siswa dalam mempelajari ilmu kimia dapat bersumber pada kesulitan dalam memahami istilah, kesulitan dalam memahami konsep kimia, kesulitan dalam hafalanserta kesulitan dalamperhitungan [4]. Dari kesulitan-kesulitan tersebut, seorang guru kimia diharapkan dapat memberikan motivasi dan mengajarkan materi kimia dengan lebih menarik dan inovatif. Untuk menyajikan materi kimia menjadi lebih menarik, guru harus memiliki kemampuan dalam mengembangkan metode dan pemanfaatan media pembelajaran.

Tabel 1. Nilai Rata-rata Ulangan Harian Kimia Kelas XI Semester Genap SMA Negeri 2 Boyolali Tahun Ajaran 2015/2016.

\begin{tabular}{cccccc}
\hline & & \multicolumn{4}{c}{ Rata-Rata Nilai } \\
\cline { 3 - 6 } Kelas & $\begin{array}{c}\text { Jumlah } \\
\text { Siswa }\end{array}$ & $\begin{array}{c}\text { Asam } \\
\text { Basa }\end{array}$ & $\begin{array}{c}\text { Larutan } \\
\text { Penyang- } \\
\text { ga }\end{array}$ & $\begin{array}{c}\text { Hidro- } \\
\text { lisis }\end{array}$ & Ksp \\
\hline XI IPA 1 & 34 & 67 & 70 & 60 & 69 \\
XI IPA 2 & 34 & 69 & 68 & 53 & 70 \\
XI IPA 3 & 34 & 67 & 68 & 69 & 69 \\
XI IPA 4 & 34 & 69 & 69 & 48 & 67 \\
XI IPA 5 & 34 & 69 & 70 & 67 & 68 \\
\hline
\end{tabular}

Hidrolisis Garam merupakan salah satu materi dalam kimia yang memuat konsep, hafalan serta perhitungan. Di SMA Negeri 2 Boyolali, materi ini sering kali membuat siswa merasa kesulitan dalam penyelesaian soal-soal yang membutuhkan banyak pemahaman konsep, hafalan serta keterampilan dalam perhitungan matematika. Berdasarkan daftar nilai mata pelajaran kimia kelas XI semester genap tahun ajaran 2015/2016, Tabel 1. dapat diketahui bahwa 
nilai rata-rata untuk materi Hidrolisis Garam belum memenuhi KKM.

Tabel 1 menunjukkan bahwa nilai rata-rata pada materi Hidrolisis Garam masih belum memenuhi KKM dan merupakan yang paling rendah dibandingkan materi kimia yang lain. Di SMA Negeri 2 Boyolali, jumlah kelas XI IPA sebanyak lima kelas dimana kelima kelas tersebut memiliki tingkat ketuntasan yang masih rendah. Ketuntasan materi Hidrolisis Garam kelas XI semester 2 SMA Negeri 2 Boyolali tahun ajaran 2015/2016 dapat dilihat pada Tabel 2.

Tabel 2. Ketuntasan Materi Hidrolisis Kelas XI Semester 2 SMA Negeri 2 Boyolali Tahun Ajaran 2015/2016.

\begin{tabular}{cccc}
\hline Kelas & KKM & $\begin{array}{c}\text { Rata- } \\
\text { rata }\end{array}$ & $\begin{array}{c}\text { Ketuntasan } \\
(\%)\end{array}$ \\
\hline XI IPA 1 & 75 & 60 & 20,58 \\
XI IPA 2 & 75 & 53 & 23,53 \\
XI IPA 3 & 75 & 69 & 29,41 \\
XI IPA 4 & 75 & 48 & 14,70 \\
XI IPA 5 & 75 & 67 & 20,58 \\
\hline
\end{tabular}

Tabel 2 menunjukkan bahwa tingkat ketuntasan siswa pada materi Hidrolisis masih sangat rendah. Hal ini menunjukkan bahwa terdapat suatu ketidakberhasilan dalam proses pembelajaran. Pembelajaran yang masih bersifat konvensional yaitu pembelajran berlangsung satu arah dan guru menjadi pusat pembelajaran menjadi salah satu penyebab ketidakberhasilan proses pembelajaran tersebut. Seharusnya dalam proses pembelajaran diarahkan berpusat pada siswa yang nantinya dapat meningkatkan prestasi belajar siswa.

Upaya dalam meningkatkan prestasi belajar siswa maka diperlukan sebuah inovasi dalam pembelajaran yang terpusat pada siswa agar pembelajaran menjadi lebih efektif. Salah satu upaya untuk mengatasi permasalahan tersebut yaitu dengan menggunakan model pembelajaran kooperatif dimana guru selain sebagai pendidik juga berperan sebagai fasilitator yang berfungsi memberi pemahaman yang lebih baik kepada siswa. Salah satu model pembelajaran kooperatif yang sesuai dan dapat digunakan pada materi hidrolisis garam yang memerlukan pemahaman konsep dan perhitungan adalah model pembelajaran Team Assisted Individualization (TAI). Model TAl dapat membantu meningkatkan motivasi antar siswa dalam menghadapi kesulitan sehingga tercipta semangat dalam proses pembelajaran.

Model pembelajaran kooperatif tipe TAI merupakan metode yang efektif untuk meningkatkan prestasi belajar siswa dibidang sains [5]. Selain itu, Model pembelajaran TAI memberikan kesempatan siswa berkembang berdasarkan taraf kemampuan sendiri terhadap materi yang sesuai dengan kemampuan sebelumnya [6].

Dari ke lima kelas XI IPA yang ada di SMA Negeri 2 Boyolali, kelas XI IPA 4 merupakan kelas yang prestasinya paling rendah dibandingkan kelas-kelas lain. Hal ini menunjukkan bahwa kelas ini mengalami permasalahan dalam proses pembelajaran. Maka, kelas ini dalam proses pembelajaran selanjutnya haruslah lebih inovatif. Rata-rata kelas XI IPA 4 untuk nilai Ulangan Akhir Semester 1 pelajaran kimia tahun ajaran 2016/2017 paling rendah dibangdingkan kelas lain. Nilai UAS murni kimia kelas XI Semester 1 Tahun Ajaran 2016/2017 dapat dilihat pada Tabel 3.

Tabel 3. Nilai Ulangan Akhir Semester Mata Pelajaran Kimia Kelas XI IPA SMA Negeri 2 Boyolali Tahun Ajaran 2016/ 2017

\begin{tabular}{ccc}
\hline Kelas & Jumlah Siswa & $\begin{array}{c}\text { Nilai Rata-Rata } \\
\text { UAS Kimia }\end{array}$ \\
\hline XI IPA 1 & 35 & 61 \\
XI IPA 2 & 34 & 60 \\
XI IPA 3 & 35 & 60 \\
XI IPA 4 & 35 & 57 \\
XI IPA 5 & 34 & 59 \\
\hline
\end{tabular}


Model TAI dipilih karena di dalam kelas yang akan diberi tindakan yaitu kelas XI IPA 4 mempunyai nilai rata-rata paling rendah dibandingkan kelas lain. TAl merupakan model pembelajaran yang menerapkan dua hal, yaitu belajar dengan kemampuan masing-masing individu dan belajar bersama kelompok. Inti dari model pembelajaran TAl ini adalah pembelajaran dengan membentuk kelompok-kelompok kecil heterogen yang terdiri dari 4 sampai 5 siswa dalam satu kelompok, diikuti dengan pemberian bantuan secara individu bagi siswa yang memerlukannya [7]. Di dalam satu kelompok pada pembelajaran TAI, terdapat seorang siswa yang lebih dalam hal aktivitas dan prestasinya yang mampu berperan sebagai asisten dan membantu siswa lain di dalam satu kelompoknya yang mendapat kesulitan dalam proses pembelajaran.

Hampir semua materi kimia kelas $\mathrm{XI}$ di semester dua memerlukan pemahaman konsep yang baik. Model TAI dipilih karena dapat meningkatkan pemahaman konsep siswa. Model pembelajaran TAI merupakan model pembelajaran yang efektif dan dapat meningkatkan prestasi belajar siswa terhadap matematika dimana didalam mata pelajaran kimia khususnya Hidrolisis Garam memerlukan pemahaman konsep kimia dan perhitungan matematika [8]. TAI cocok digunakan untuk materi kimia yang memerlukan pemahaman konsep, rumus, dan menghitung khususnya pada materi Hidrolisis Garam.

Materi Hidrolisis Garam berkaitan erat dengan pemahaman konsep yang baik, pemahaman konsep yang baik diperlukan analisis yang baik. Hal ini erat kaitannya dengan kemampuan analisis siswa. Kemampuan analisis adalah kemampuan untuk memecahkan konsep maupun masalah yang kompleks dan rumit serta membuat keputusan yang logis atas informasi yang tersedia. Tanpa adanya kemampuan analisis terhadap materi pembelajaran, siswa tidak akan memahami dan mengemukakan kembali isi materi yang telah disampaikan oleh guru.

Dalam proses pembelajaran, model pembelajaran TAI dapat ditunjang dengan media pembelajaran yang baik. Salah satu media pembelajaran yang dapat digunakan yaitu Lembar Kerja Siswa (LKS) berbasis Drill and Practice. LKS berbasis Drill and Practicemerupakan media yang berisi ringkasan materi dan soal-soal latihan yang berkaitan dengan materi pelajaran. Drill and Practicetepat diterapkan dalam pembelajaran materi hitungan, dan perbendaharaan kata-kata yang memerlukan pemahaman konsep [9]. Media ini dapat digunakan untuk menunjang proses pembelajaran dengan model TAl pada materi Hidrolisis Garam yang melibatkan pemahaman konsep dan perhitungan.

\section{METODE PENELITIAN}

Penelitian ini merupakan Penelitian Tindakan Kelas (Classroom Action Research). Prosedur Penelitian Tindakan Kelas ini dilaksanakan dalam dua siklus. Prosedur yang digunakan dalam melaksanakan Penelitian Tindakan Kelas (PTK) ini berupa model spiral. Ada empat tahap dalam model spiral yaitu perencanaan (planning), indakan (acting), pengamatan (observing), dan releksi (reflecting)[3].

Subjek penelitian adalah siswa kelas XI IPA 4 SMA Negeri 2 Boyolali Tahun Ajaran 2016/2017 yang berjumlah 34 siswa. Pemilihan subjek dalam penelitian ini didasari pada pertimbangan bahwa subjek tersebut mengalami permasalahan yang telah teridentifikasi pada saat observasi awal. Objek peneitian ini adalah prestasi belajar siswa (kognitif, afektif, dan psikomotor) dan kemampuan analisis siswa terhadap pembelajaran yang diterapkan.

Data yang dikumpulkan dalam penilitian ini meliputi data informasi tentang keadaan siswa dilihat dari aspek kualitati dan kuantitatif. Aspek kualitatif berupa data hasil observasi, wawancara, kajian dokumen, dan pemberian angket. Aspek kuanti- 
tatif berupa tes prestasi belajar dan tes kemampuan analisis.

Analisis data dalam Penelitian Tindakan Kelas (PTK) dimulai sejak awal sampai berakhirnya pengumpulan data. Data-data dari hasil penelitian di lapangan diolah dan dianalisis secacara kualitatif. Analisis kualitatif yang dimaksud adalah analisis deskriptif. Teknik analisis juga mengacu pada model analisis Miles dan Huberman yang dilakukan dalam tiga komponen yaitu reduksi data, penyajian data, penarikan kesimpulan, dan verifikasi[10]

Teknik validasi data yang digunakan dalam penelitian ini adalah triangulasi. Triangulasi adalah teknik pemeriksaan data yang memanfaatkan sesuatu yang lain diluar data itu untuk keperluan pengecekan atau pembanding terhadap data itu. Teknik triangulasi yang digunakan adalah triangulasi metode[11]. Dalam penelitian ini peneliti menggunakan metode pengumpulan data melalui teknik observasi, wawancara, kajian dokumen, angket, dan tes.

\section{HASIL DAN PEMBAHASAN}

Observasi awal tanggal 16 Januari 2017 menunjukkan proses pembelajaran masih berpusat pada guru, selain itu berdasarkan kajian dokumen menunjukkan bahwa penguasaan siswa terhadap materi hidrolisis masih sangat rendah. Hal ini menyebabkan proses pembelajaran menjadi pasif. Padahal keterlibatan dan penguasaan konsep siswa dalam proses kegiatan belajar mengajar dapat dijadikan indikator keberhasilan dari kualitas pembelajaran yang dapat dilihat dari perolehan prestasi belajar siswa. Salah satu faktor yang mempengaruhi pemahaman konsep adalah kemampuan analisis. Oleh karena itu, kemampuan analisis perlu dikembangkan dalam proses pembelajaran. Salah satu sarana untuk mengasah kemampuan analisis siswa ialah melalu model pembelajaran kooperatif Team Assisted
Individualization (TAI). Unsur dalam TAI yang diperkirakan dapat meningkatkan kemampuan analisis siswa adalah saat siswa mengidentifikasi dan menganalisis informasi untuk memecahkan masalah dengan saling bertukar pendapat dalam diskusi kelompok. Dengan meningkatnya kemampuan analisis siswa maka kesulitankesulitan yang dialami oleh siswa terkait dengan materi akan dapat teratasi, sehingga prestasi belajar siswa dapat meningkat.

\section{Siklus I}

Pada tahap perencanaan, peneliti bersama guru menyiapkan silabus, RPP, media pembelajaran, instrumen penelitian, dan merencanakan jadwal penelitian. Pembelajaran direncanakan terdiri dari 8 jam pelajaran (4 kali tatap muka) yaitu $6 \times 45$ menit untuk penyampaian materi dan $2 \times 45$ menit untuk tes evaluasi siklus I.

Berdasarkan perencanaan tindakan yang telah dilakukan oleh peneliti, kemudian diterapkan di kelas XI IPA 4 SMA Negeri 2 Boyolali. Proses pembelajaran menggunakan model pembelajaran Team Assisted Individualization (TAI), siswa dibagi menjadi 8 kelompok masing-masing terdiri dari 4-5 siswa dengan salah satu anggota menjadi asisten. Kemudian guru memberikan garis besar materi yang dipelajari. Siswa kemudian berdiskusi. Selanjutnya dilaksanakan presentasi dan penghargaan kelompok. Kemudian guru memberi penekanan-penekanan mengenai materi dan membimbing siswa membuat kesimpulan.

Akhir siklus I dilaksanakan tes kognitif, tes kemampuan analisis, dan pemberian angket afektif. Penlaian untuk tes aspek kognitif didapatkan ketuntasan sebanyak 20 siswa dari 34 siswa. Sehingga presentase ketutansan aspek pengetahuan siswa kelas XI IPA 4 adalah 58,82\%. Penilaian aspek afektif menggunakan angket serta observasi. Hasil belajar aspek afektif diperoleh ketuntasan sebesar 94\%. Penilaian untuk aspek psikomotor yaitu observasi dan laporan praktikum dan didapat ketuntasan sebesar $80 \%$. Penilaian untuk aspek kemampuan analisis siswa menggunakan 
tes. Hasil tes kemampuan analisis siswa diperoleh ketuntasan sebesar 50\%. Ketercapaian masing-masing aspek pada siklus I disajikan dalam Tabel 4.

Tabel 4 Hasil Ketercapaian Siklus I Materi Hidrolisis Kelas XI IPA 4 SMA Negeri 2 Boyolali Tahun Ajaran 2016/2017

\begin{tabular}{cccc}
\hline \multirow{2}{*}{ Aspek } & \multicolumn{2}{c}{ Siklus I (\%) } & \multirow{2}{*}{ Kriteria } \\
\cline { 2 - 3 } & Capaian & Target & \\
\hline Kognitif & 58,82 & 70,00 & Belum \\
Afektif & 94,00 & 70,00 & Tercapai \\
$\begin{array}{c}\text { Psikomotor } \\
\text { Kemampuan } \\
\text { Analisis }\end{array}$ & 80,00 & 75,00 & Tercapai \\
\hline
\end{tabular}

Tabel 4 menunjukkan bahwa prestasi belajar kognitif belum mencapai target, sehingga perlu dilakukan perbaikan di siklus II, sedangkan untuk aspek afektif, psikomotor dan kemampuan analisis sudah mencapai target siklus I namun tetap dilaksanakan siklus II untuk memenuhi target indikatorindikator yang belum tercapai serta untuk mengetahui besar peningkatannya.

\section{Siklus II}

Setelah dilakukan tindakan refleksi pada siklus I maka dilakukan perencanaan untuk pelaksanaan tindakan pada siklus II. Pada pembelajaran siklus II difokuskan pada indikator kompetensi yang belum tercapai. Guru mengulang kembali indikator kompetensi pada aspe kogniti yang belum tuntas, yaitu Menghitung $\mathrm{pH}$ garam yang terhidrolisis. Asisten di siklus II dipilih berdasarkan nilai terbaik saat siklus I .

Pada pertemuan terakhir siklus II diberikan tes kognitif, angket afektif dan tes kemampuan analisis. Hasil tes kognitif diperoleh ketuntasan siswa sebesar $79,41 \%$, aspek afektif sebesar $97 \%$, dan kemampuan analisis sebesar $70 \%$. Hasil dari aspek kognitif sudah mencapai target yang ditetapkan. Sedangkan aspek afektif dan kemam- puan analisis mengalami peningkatan. Aspek psikomotor tidak dilakukan di siklus II selain karena telah tuntas pada siklus I juga karena keterbatasan waktu pada saat penelitian. Ketercapaian masing-masing aspek di siklus II disajikan dalam Tabel 5.

Tabel 5 Hasil Ketercapaian Siklus II Materi Hidrolisis Kelas XI IPA 4 SMA Negeri 2 Boyolali Tahun Ajaran 2016/2017

\begin{tabular}{cccc}
\hline \multirow{2}{*}{ Aspek } & \multicolumn{2}{c}{ Siklus II (\%) } & \multirow{2}{*}{ Kriteria } \\
\cline { 2 - 3 } & Capaian & Target & \\
\hline Kognitif & 79,41 & 70,00 & Tercapai \\
Afektif & 97,00 & 70,00 & Tercapai \\
Kemampuan & 70,00 & 50,00 & Tercapai \\
Analisis & &
\end{tabular}

\section{Perbandingan Antar Siklus}

Perbandingan hasil tindakan antar siklus bertujuan untuk mengetahui peningkatan yang terjadi selama tindakan siklus I dan siklus II. Perbandingan hasil tindakan antar siklus disajikan dalam Tabel 6 .

Tabel 6. Perbandingan Hasil Tindakan antar Siklus Materi Hidrolisis Kelas XI IPA 4 SMA Negeri 2 Boyolali Tahun Ajaran 2016/2017

\begin{tabular}{cccc}
\hline \multirow{2}{*}{ Aspek } & \multicolumn{2}{c}{ Capaian (\%) } & \multirow{2}{*}{ Kriteria } \\
\cline { 2 - 3 } & Siklus I & Siklus II & \\
\hline Kognitif & 58,82 & 79,41 & Tercapai \\
Afektif & 94,00 & 97,00 & Tercapai \\
Psikomotor & 80,00 & - & Tercapai \\
Kemampuan & 50,00 & 70,00 & Tercapai \\
Analisis & & & \\
\hline
\end{tabular}

Tabel 6. menunjukkan bahwa terjadi peningkatan dari siklus I ke siklus II. Aspek kognitif pada siklus II dapat mencapai target, sedangkan aspek afektif dan kemampuan analisis siswa meningkat di siklus II. Penelitian Tindakan Kelas (PTK) dinyatakan berhasil apabila masing-masing aspek yang diukur telah mencapai target yang telah ditetapkan.

\section{KESIMPULAN}

Pembelajaran kooperatif model Team Assisted Individualization (TAI) dilengkapi 
LKS berbasis Drill and Practice dapat meningkatkan prestasi belajar siswa dan kemampuan analisis siswa pada materi hidrolisis kelas XI IPA 4 SMA Negeri 2 Boyolali Tahun Ajaran 2016/2017.

\section{UCAPAN TERIMA KASIH}

Peneliti mengucapkan terima kasih kepada ibu Nur Heni Widiastuti, S.Pd. selaku guru mata pelajaran kimia SMA Negeri 2 Boyolali serta seluruh pihak yang turut berperan dalam penelitian ini.

\section{DAFTAR RUJUKAN}

[1] Sudjana, N. (1996). Metoda Statistika. Bandung: Tarsito

[2] Badan Standar Nasional Pendidikan. (2006). Panduan Penyusunan Kurikulum Tingkat Satuan Pendidikan Jenjang Pendidikan Dasar dan Menengah. Jakarta: Departemen Pendidikan Nasional

[3] Arikunto, S, Suhardjono, \& Supardi. 2009. Penelitian Tindakan Kelas. Jakarta: PT Bumi Aksara.

[4] Arifin, M. (1995). Pengembangan Program Pengajaran Bidang Studi Kimia. Surabaya: Airlangga University Press
[5] Nneji, L. (2011). Impact of Framing and Team Assisted Individualized Instructional Strategies Students Achievement in Basic Science in The North Central Zone of Nigeria. Knowledge Review, 23(4), 1-8.

[6] Slavin, R.E. (2008). Cooperative Learning : Teori, Riset, dan Praktik Terj. Nurlita Yusron. Bandung : Nusa Media.

[7] Shillahaque, G.P., Mulyani, B., Agustina W. (2015). Penerapan Model Pembelajaran Team Assisted Individualization (TAI) dengan Media KeyRelation Chart (KR-Chart). Jurnal Pendidikan Kimia, 4 (4), 1-7.

[8] Awofala, A.O.A., Arigbabu, A.A., Awofala, A.A. (2013). Acta Didactica Napocensia, 6 (1), 1-22

[9] Sharon. (2005). Ideologies, Practice, and Their Implication for Special Education. Journal of Special Education, 2005, vol. 28, 44-56.

[10] Miles, M., \& Huberman, A.M. (1992). Analisis Data Kualitatif Terj. Cecep Rohendi Effendi. Jakarta: UI Press.

[11] Moleong, L.J. (2013). Metodologi Penelitian Kualitatif Terj. Sonny Keraf. Bandung: PT Remaja Rosdakarya 